\title{
Thrips parvispinus Karny (Thysanoptera: Thripidae) pada Tanaman Cabai: Perbedaan Karakter Morfologi pada Tiga Ketinggian Tempat
}

\author{
DEWI SARTIAMI*, MAGDALENA, DAN ALI NURMANSYAH
}
Departemen Proteksi Tanaman, Fakultas Pertanian, Institut Pertanian Bogor
Jalan Kamper, Kampus IPB Darmaga, Bogor 16680,

(diterima Mei 2011, disetujui Juli 2011)

\begin{abstract}
ABSTRAK
Thrips parvispinus Karny (Thysanoptera: Thripidae) pada Tanaman Cabai: Perbedaan Karakter Morfologi pada Tiga Ketinggian Tempat. Salah satu hama penting pada tanaman cabai adalah Thrips parvispinus Karny (Thysanoptera: Thripidae). Keberadaannya terdeteksi mulai dari dataran rendah sampai dataran tinggi. Penelitian ini bertujuan untuk mengetahui keragaman morfologi $T$. parvispinus pada tiga ketinggian tempat yang berbeda yakni: Cirebon (<30 mdpl), Bogor (300-400 mdpl), dan Cianjur (>1200 mdpl). Pada masing-masing lokasi dikoleksi 60 ekor trips betina dan kemudian diawetkan dalam preparat mikroskop dengan media Hoyer. Karakter morfologi $T$. parvispinus yang diamati adalah ukuran panjang tubuh, lebar kepala, lebar toraks, panjang sayap, dan warna tubuh. Perbedaan karakter morfologi tubuh trips pada ketiga ketinggian tempat dianalisis menggunakan sidik ragam dan uji kisaran berganda Duncan. Korelasi antara ketinggian tempat dan perubahan warna tubuh trips dianalisis dengan uji khi kuadrat. Hasil penelitian menunjukkan bahwa panjang tubuh, lebar toraks, dan panjang sayap trips yang berasal dari dataran tinggi lebih panjang daripada dataran sedang dan rendah. Ketiga karakter morfologi tersebut menunjukkan perbedaan yang nyata antara dataran sedang dan dataran rendah dengan dataran tinggi, kecuali karakter lebar kepala. Perubahan warna kepala, toraks, dan abdomen berkorelasi dengan ketinggian tempat.
\end{abstract}

KATA KUNCI: Thrips parvispinus, karakter morfologi, ketinggian tempat, cabai.

\begin{abstract}
Thrips parvispinus Karny (Thysanoptera: Thripidae) on Chili Plants: Morphological Differences in the Three Character Height Place. One of the important pests on chilli plants is Thrips parvispinus Karny (Thysanoptera: Thripidae). The presence of the pest is detected ranging from lowlands to highlands. This study was aimed to find out the morphological diversity of T. parvispinus at three different altitudes which include Cirebon (<30 m asl), Bogor (300 - $400 \mathrm{~m}$ asl), and Cianjur (> 1200 $\mathrm{m}$ asl). At each level of altitude, it was collected 60 female adults of the thrips and then they were preserved into microscope preparations using
\end{abstract}

\footnotetext{
*Korespondensi:

Telp.: +62-251-8629364,

Faks: 0251-8629362, E-mail: dsartiami@yahoo.com
} 


\begin{abstract}
Hoyer medium. The observed morphological characters of $T$. parvispinus were the length of body, the width of head, the width of thorax, the length of wing, and the color of body. The difference in morphological characters of the thrips in all three levels of altitude were analyzed using analysis of variance and Duncan's multiple range test. The correlation between altitude and body color was analyzed using chi- square test. Results showed that the body length, thoracic width, and wing length of the highland thrips were longer than those of the mid and lowland thrips. The three morphological characters showed significant differences between the mid and lowlands and the highlands, except for the character of head width. Changes in the color of the head, thorax, and abdomen were correlated to the level of the altitude.
\end{abstract}

KEY WORDS: Thrips parvispinus, morphological character, altitude, chilli.

\section{PENDAHULUAN}

Thrips parvispinus Karny (Thysanoptera: Thripidae) merupakan hama penting pada tanaman cabai (Kalshoven 1981) dan menjadi hama utama pada pertanaman cabai di pulau Jawa, terutama ketika musim kemarau (Vos 1991). Seperti halnya kelompok trips fitofag lainnya, serangga ini merusak tanaman dengan cara memarut-menghisap (Lewis 1973). Kerusakan yang ditimbulkan pada daun cabai berupa bercak keperakan (Prabaningrum \& Moekasan 1996). Selain itu, Vos (1991) menyatakan bahwa serangan berat $T$. parvispinus pada tanaman cabai dapat menyebabkan bercak keperakan menjadi kecoklatan dan daun mengeriting dengan arah ke atas. Saat ini diketahui bahwa $T$. parvispinus juga berperan sebagai vektor virus TSV (Tobacco streak ilarvirus) (Klose et al. 1996). Kehilangan hasil akibat serangan $T$. parvispinus pada pertanaman cabai mencapai $22,8 \%$ (Sastrosiswojo 1991).
Hama T. parvispinus bersifat polifag, diketahui menyerang tanaman Crotalaria sp., Vigna sp., mentimun, ubi jalar, tembakau, dan cabai (Kalshoven 1981). Spesies trips ini diyakini berasal dari Asia Tenggara (Mound \& Collins 2000; Anagnou-Veroniki 2008; California University 2009) tetapi serangga ini diketahui telah menyebar ke belahan bumi lainnya. Mound \& Collins (2000) melaporkan T. parvispinus masuk ke Negara Yunani pada tahun 1997 terbawa bunga potong Gardenia yang diimpor negara tersebut dari Indonesia. Serangga T. parvispinus juga dilaporkan merupakan hama penting di Amerika Serikat, terutama pada pertanaman pepaya di negara bagian Hawaii (California University 2009), dan di Malaysia (Mound \& Azidah 2009). Lebih lanjut dikatakan bahwa serangga ini menyebar dari Asia Tenggara ke Papua Nugini, Kepulauan Micronesia, dan Australia Utara (California University 2009).

Berdasarkan pengamatan pendahuluan pada beberapa area pertanaman 
cabai, diketahui bahwa terdapat variasi ukuran dan warna tubuh imago betina T. parvispinus. Hal ini didukung oleh hasil penemuan Prabaningrum (2005), pada tanaman paprika dalam rumah kaca. Prabaningrum melaporkan bahwa ukuran tubuh betina $T$. parvispinus antara 0,99-1,35 $\mathrm{mm}$ dengan variasi warna coklat muda sampai dengan coklat tua. Lebih jauh Prabaningrum (2005) menyatakan bahwa kelompok individu yang berukuran panjang dan berwarna coklat tua dominan terhadap kelompok lainnya. Mound \& Collin (2000) melaporkan adanya variasi bentuk $T$. parvispinus pada sampel trips yang masuk ke Negara Yunani. Menurut Nahrung \& Allen (2005), perbedaan karakter warna individu dalam spesies yang sama dapat terjadi karena faktor lingkungan, seperti jenis makanan, suhu, kelembapan, atau faktor genetik. Berdasarkan adanya variasi individu dalam populasi $T$. parvispinus, maka penelitian ini bertujuan mengetahui perbedaan karakter morfologi T. parvispinus pada tanaman cabai merah di tiga tempat pada ketinggian berbeda, yaitu Cirebon, Bogor, dan Cianjur.

\section{BAHAN DAN METODE}

Pengambilan sampel dilakukan di Ciledug (Cirebon), Cibeureum, dan Cinangneng (Bogor), dan Cipendawa (Cianjur). Identifikasi serta pengamatan morfologi tubuh $T$. parvispinus dilakukan di Laboratorium Biosiste- matika Serangga Departemen Proteksi Tanaman, Fakultas Pertanian, Institut Pertanian Bogor. Penelitian dilakukan dari bulan Febuari sampai Agustus 2008.

\section{Pengambilan Sampel dari Lapangan}

Sampel trips berasal dari pertanaman cabai pada tiga ketinggian tempat yaitu: Ciledug - Cirebon yang mewakili dataran rendah ( $<100 \mathrm{mdpl})$, Cibeureum dan Cinangneng - Bogor mewakili dataran sedang (300-400 mdpl), serta Cipendawa - Cianjur mewakili dataran tinggi (>1200 mdpl). Ketinggian tempat dan letak lintang diukur menggunakan GPS (Global Positioning System) Magellan Tipe 315. Pengambilan sampel trips setiap petak pertanaman cabai dilakukan menggunakan metode diagonal. Jumlah sampel yang diambil pada setiap petak pertanaman adalah 9 tanaman. Tanaman sampel tersebut tidak termasuk tanaman pinggir. Pengambilan sampel dilakukan saat usia tanaman 7 mst (minggu setelah tanam). Pengambilan sampel trips dilakukan dengan cara menepuk-nepuk bagian bunga tanaman di atas baki plastik berwarna putih. Jumlah sampel yang dikumpulkan adalah 60 ekor betina. Sampel tersebut kemudian dimasukkan ke dalam tabung eppendorf yang berisi alkohol $80 \%$ menggunakan kuas halus. Tabung tersebut kemudian diberi label yang mencakup informasi tanggal peng- 
ambilan, lokasi, tanaman inang, dan nama kolektor.

\section{Pembuatan Preparat Mikroskop Thrips parvispinus}

Pembuatan preparat diawali dengan penataan imago trips betina saat masih berada dalam larutan alkohol, yakni dengan merentangkan kedua sayap serangga serta meluruskan antena. Bagian ventral tubuh berada di sebelah atas. Larutan Hoyer diteteskan pada kaca penutup yang berdiameter $13 \mathrm{~mm}$, kemudian trips yang telah diatur posisinya diletakkan pada kaca penutup tersebut dan segera ditutup menggunakan kaca obyek. Segera setelah kaca obyek menempel pada larutan Hoyer, kaca ini dibalik sehingga kaca penutup berada di atas kaca obyek. Objek tersebut kemudian dikeringkan pada hot plate bersuhu 35$40^{\circ} \mathrm{C}$ selama 3 minggu.

\section{Identifikasi Spesies Trips}

Identifikasi trips dilakukan di bawah mikroskop cahaya dengan perbesaran 4, 10, dan 40 kali. Identifikasi mengacu pada literatur Identifikasi Thysanoptera edisi ke-2 oleh Mound dan Kibby (1998), serta program identifikasi Lucid (Moritz et al. 2004).

\section{Pengamatan Ukuran Dan Warna Tubuh Trips}

Sampel trips diamati di bawah mikroskop binokuler. Pengukuran lebar kepala, panjang tubuh, lebar toraks dan panjang sayap trips dilakukan menggunakan mikrometer. Pengamat- an warna tubuh trips meliputi warna kepala, toraks, dan abdomen. Pengamatan warna dilakukan menggunakan Munsell Soil Color Chart.

\section{Pengolahan Data}

Data ukuran tubuh $T$. parvispinus diolah menggunakan sidik ragam yang dilanjutkan dengan uji Jarak Berganda Duncan pada taraf nyata 5\% menggunakan program Statistical Analytic Software (SAS) versi 6.12. Korelasi warna tubuh dengan ketinggian tempat dianalisis menggunakan uji khi kuadrat dengan bantuan program MINITAB 14.

\section{HASIL DAN PEMBAHASAN}

\section{Identifikasi $T$. parvispinus}

Tubuh imago betina $T$. parvispinus berwarna coklat. Bagian kepala dan toraks lebih pucat dibandingkan warna abdomen. Tungkai pada umumnya berwarna kuning.

Pada bagian kepala $T$. parvispinus terdapat sepasang antena yang terdiri atas tujuh ruas. Pada ruas kedua dan ketiga terdapat organ sensori yang berbentuk kerucut bercabang seperti garpu. Antena segmen ketiga berwarna kuning, demikian pula segmen keempat dan kelima namun hanya setengahnya yang berwarna kuning. Antena segmen ketujuh berukuran sangat kecil. Oseli berwarna merah. Seta oseli 1 tidak ada. Seta oseli 2 lebih pendek dibandingkan seta oseli 3 . 


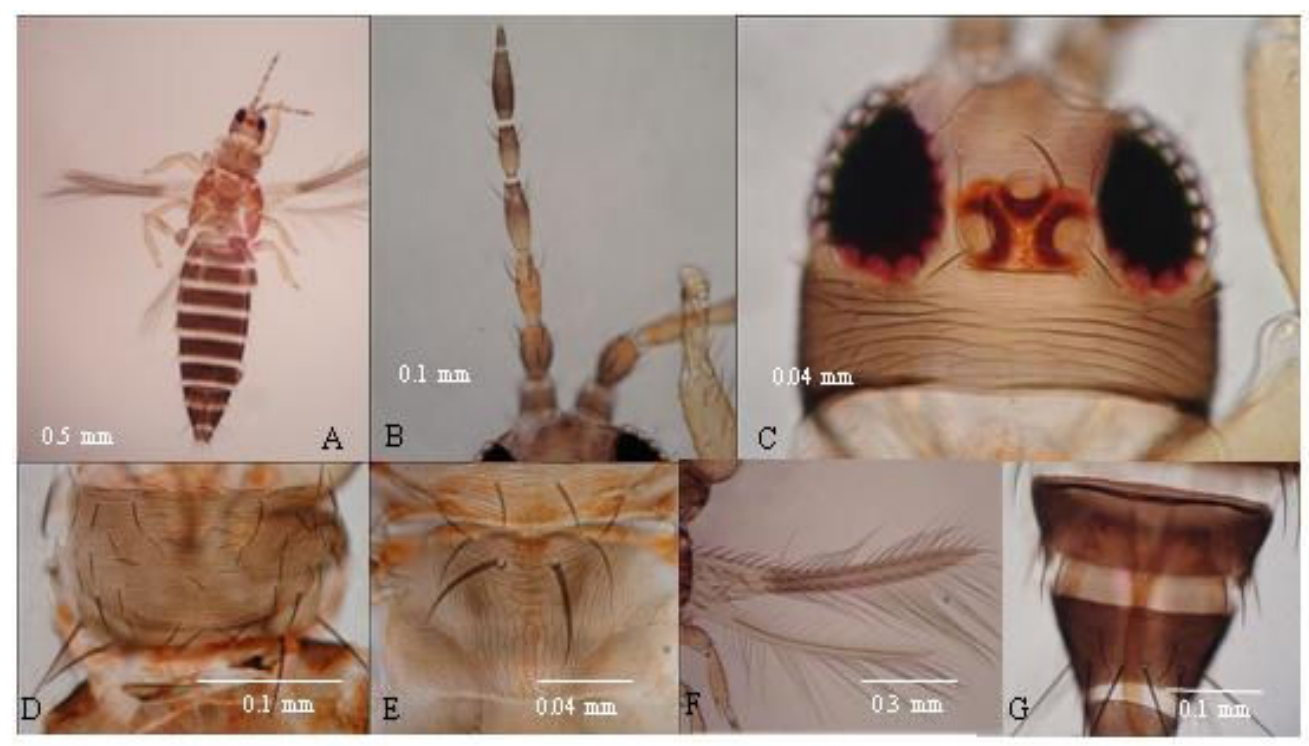

Gambar 1. Morfologi T. parvispinus (A, imago betina; B, antena; C, kepala; D, pronotum; E, metanotum; F, sayap; G, tergit VIII)

Seta oseli 3 terletak pada bagian pinggir bagian depan segitiga oseli. Maksila berkembang dengan baik. Labrum terletak di bagian depan, sedangkan labium terletak di bagian belakang.

Toraks T. parvispinus memiliki dua pasang seta posteroangular yang panjang dan tiga pasang posteromarjinal. Metanotum memiliki pola retikulasi seperti kotak dengan ukuran yang serupa (equiangular). Tidak terdapat sensila kampaniform dan memiliki mesofurka dengan spinula. Trips ini memiliki sepasang sayap berumbai. Panjang sayap T. parvispinus lebih dari setengah panjang abdomennya. Sayap T. parvispinus berwarna gelap atau transparan. Pangkal sayap berwarna pucat. Pada venasi pertama dan kedua sayap depan terdapat sederet seta yang lengkap.
Abdomen $T$. parvispinus terdiri atas 11 ruas. Pada tergit 8 tidak terdapat comb (deretan mikrotrikhia). Pada bagian sisi tergit 5 sampai 8 terdapat ctenidia. Ctenidia pada tergit 8 terletak di bagian belakang spirakel.

\section{Panjang Tubuh T. parvispinus}

Rata-rata panjang tubuh $T$. parvispinus dari ketiga lokasi pengamatan menunjukkan adanya variasi pada hasil pengukuran di ketiga lokasi tersebut. Terdapat indikasi bahwa sampel $T$. parvispinus di dataran tinggi memiliki ukuran tubuh lebih besar dan berbeda nyata dengan $T$. parvispinus di dataran rendah dan sedang (Tabel 1). Sebelumnya Mound \& Collin (2000) telah menemukan adanya variasi morfologi pada T. parvispinus.

Hasil penelitian ini serupa dengan penemuan Oliviera et al. (2004) pada 
Tabel 1. Rata-rata ukuran tubuh $T$. parvispinus pada berbagai ketinggian tempat

\begin{tabular}{|c|c|c|c|c|c|c|}
\hline \multirow[t]{2}{*}{ Lokasi } & \multirow{2}{*}{$\begin{array}{c}\text { Ketinggian } \\
\text { tempat } \\
(\mathrm{mdpl})\end{array}$} & \multirow[t]{2}{*}{ Suhu $\left({ }^{\circ} \mathrm{C}\right)$} & \multicolumn{4}{|c|}{ Ukuran tubuh $(\mathrm{mm})^{1)}$} \\
\hline & & & Panjang tubuh & Lebar kepala ${ }^{2)}$ & Lebar toraks & Panjang sayap \\
\hline Cianjur & $1200-1207$ & $20,7 \pm 0,72$ & $1,408 \pm 0,077 \mathrm{a}$ & $0,171 \pm 0,012 \mathrm{a}$ & $0,351 \pm 0,035 a$ & $0,714 \pm 0,036 a$ \\
\hline Bogor & $394-290$ & $25,5 \pm 0,73$ & $1,367 \pm 0,065 b$ & $0,165 \pm 0,010 \mathrm{~b}$ & $0,343 \pm 0,039 b$ & $0,673 \pm 0,040 b$ \\
\hline Cirebon & $21-27$ & $26,7 \pm 0,08$ & $1,350 \pm 0,079 b$ & $0,170 \pm 0,012 \mathrm{a}$ & $0,335 \pm 0,034 b$ & $0,662 \pm 0,032 b$ \\
\hline
\end{tabular}

Dalbulus maidis (Hemiptera: Cicadellidae) bahwa berat tubuh, ukuran tubuh, lebar kapsul kepala, serta lebar sayap berkorelasi positif dengan ketinggian suatu tempat dari permukaan laut. Hasil penelitian Parkash et al. (2009) pada Drosophila melanogaster (Diptera: Drosophilidae) juga menunjukkan bahwa populasi serangga yang hidup di dataran tinggi memiliki ukuran tubuh yang lebih besar dibandingkan populasi yang hidup di dataran yang rendah. Blackman \& Spence (1994) yang didukung oleh beberapa hasil penelitian pada beberapa genus serangga menyatakan bahwa serangga dapat tumbuh dan berkembang dengan maksimum pada suhu yang lebih rendah.

Pada umumnya lebar kepala trips berkorelasi positif dengan ketinggian tempat, kecuali untuk trips yang berasal dari daerah Cirebon. Lebar kepala trips di daerah ini tidak berbeda nyata dengan lebar kepala trips yang berasal dari daerah Cianjur. Hal ini menunjukkan bahwa keterkaitan antara ukuran kepala dengan ketinggian tepat kurang kuat dibandingkan karakter panjang tubuh, lebar toraks, dan panjang abdomen.

Cianjur, Bogor, dan Cirebon berada pada ketinggian berbeda dari permukaan laut (Tabel 1). Perbedaan ketinggian suatu tempat berasosiasi dengan perbedaan suhu di tempat tersebut. Prabaningrum (2005) menyatakan bahwa semakin tinggi suatu tempat dari permukaan laut, suhu di tempat tersebut semakin rendah. Lebih lanjut Prabaningrum (2005) menyatakan bahwa ukuran tubuh trips dipengaruhi oleh keturunan, kualitas, kuantitas makanan, dan suhu lingkungan. Parkash et al. (2009) juga menyatakan bahwa ketinggian suatu tempat berkorelasi negatif dengan suhu. Kedua pernyataan tersebut menjelaskan perbedaan bentuk tubuh trips pada tiga lokasi penelitian.

Seperti halnya jenis serangga lain, trips merupakan hewan berdarah dingin, atau dikenal dengan istilah organisme ekotermik (Forsman et al. 2002). Pada organisme ini, suhu tubuh, proses fisiologi, serta perilaku sangat 
dipengaruhi oleh kondisi temperatur eksternal. Dixon (1985) menyatakan bahwa serangga yang hidup pada suhu lebih tinggi umumnya memiliki ukuran tubuh yang lebih pendek. Hal ini dipertegas oleh beberapa hasil penelitian yang mengungkapkan bahwa populasi satu spesies serangga yang hidup di lingkungan dengan suhu lebih tinggi memiliki ukuran tubuh lebih pendek dibandingkan populasi yang hidup di lingkungan dengan suhu lebih rendah, diantaranya Oliviera et al. (2004) pada D. maidis, Prakash et al. (2009) pada D. melanogaster, Fischer \& Karl (2010) pada Cooper butterflies (Lepidoptera: Lycaenidae), serta Murai \& Toda (2002) pada populasi $T$. tabaci.

Morfologi imago suatu serangga sangat ditentukan oleh kondisi lingkungan selama masa larva hingga menjadi pupa (Schoonhoven et al. 2005; Berger et al. 2008). Murai \& Toda (2002) menemukan bahwa larva $T$. tabaci yang diperbanyak pada lingkungan bersuhu hangat menghasilkan imago yang berukuran lebih kecil dibandingkan larva yang hidup pada lingkungan bersuhu dingin. Hal yang sama juga ditemukan Blackman \& Spence (1994) pada koloni kutu daun.

Berger et al. (2008) menyatakan bahwa pada suhu lebih rendah imago akan menimbun energi yang dimilikinya untuk membentuk struktur tubuh, sedangkan pada suhu lebih tinggi, imago akan mengalihkan energi yang dimilikinya untuk memproduksi telur yang lebih banyak. Dalam penelitian ini, jumlah telur yang dihasilkan imago T. parvispinus tidak diamati. Hal tersebut dapat menjadi masukan untuk perbaikan penelitian berikutnya.

\section{Warna Tubuh T. parvispinus}

Secara umum, T. parvispinus berwarna coklat dengan tingkat kepekatan yang bervariasi, bergantung pada lokasi pengambilan sampel. Hal ini sesuai dengan pernyataan Mound \& Collins (2000) bahwa sampel imago betina $T$. parvispinus yang diambil dari beberapa negara (Singapura, Thailand, Indonesia, dan Taiwan) menunjukkan warna coklat yang bervariasi. Sebelumnya Honek \& Furlan (1995) juga menyatakan bahwa berdasarkan penelitian pada Agriotes ustulatus (Coleoptera: Elateridae), variasi temporal dan geografi suatu tempat sangat berpengaruh terhadap variasi frekuensi melanisasi. Pada penelitian ini, warna tubuh betina $T$. parvispinus pada tiga lokasi observasi menunjukkan ada 11 variasi warna kepala, toraks, dan abdomen.

Walaupun hasil pengamatan menunjukkan adanya variasi yang cukup tinggi, terdapat satu jenis warna dominan untuk setiap wilayah observasi. Warna dominan untuk daerah Cianjur adalah dark brown (coklat gelap) pada bagian kepala, olive brown (coklat hijau zaitun) dan dark brown 
(coklat gelap) untuk bagian toraks, serta dark brown (coklat gelap) untuk bagian abdomen. Pada lokasi yang terletak di dataran yang lebih rendah, yakni Bogor dan Cirebon, warna dominan untuk bagian kepala dan toraks adalah olive brown (coklat hijau zaitun), sedangkan untuk bagian abdomen adalah dark yellowish brown (coklat gelap kekuningan) (Cirebon) dan dark brown (coklat gelap) (Bogor) (Tabel 2).

Berdasarkan hasil uji khi kuadrat, terlihat bahwa warna kepala, toraks, dan abdomen berkorelasi positif dengan ketinggian tempat. Terdapat indikasi bahwa populasi $T$. parvispinus di dataran tinggi umumnya memiliki warna tubuh yang lebih gelap dibandingkan bila serangga ini hidup pada dataran yang lebih rendah. Hasil penelitian ini serupa dengan hasil penelitian Murai \& Toda (2002), begitu juga dengan hasil penelitian Parkash et al. (2009), serta Fischer \&
Karl (2010). Prabaningrum (2005) menyatakan bahwa semakin tinggi suatu tempat dari permukaan laut, suhu di tempat tersebut semakin rendah. Berdasarkan hal tersebut, maka dapat dikatakan bahwa semakin tinggi suhu lingkungan, T. parvispinus akan berwarna semakin pucat, sedangkan semakin rendah suhu lingkungan, $T$. parvispinus akan berwarna semakin gelap.

Zera (2004) menyatakan bahwa variasi fenotipe pada suatu spesies serangga dapat terjadi akibat adanya interaksi genetik dan lingkungan. Hal ini sesuai dengan pernyataan Honex \& Furlan (1995) bahwa suhu sangat mempengaruhi ekspresi gen yang mengatur melanisasi. Forsman et al. (2002) menegaskan bahwa morfologi warna yang berbeda dipengaruhi oleh genetik, akan tetapi responnya juga dipengaruhi tingkat pemanasan di lingkungan tumbuhnya. Pada penelitian ini, serta beberapa penelitian serupa

Tabel 2. Tampilan warna dominan bagian tubuh $T$. parvispinus pada berbagai ketinggian tempat

\begin{tabular}{|c|c|c|c|c|c|}
\hline \multirow[t]{2}{*}{ Lokasi } & \multirow{2}{*}{$\begin{array}{c}\text { Ketinggian } \\
\text { tempat } \\
\text { (mdpl) }\end{array}$} & \multirow[t]{2}{*}{ Suhu $\left({ }^{\circ} \mathrm{C}\right)$} & \multicolumn{3}{|c|}{ Warna dominan } \\
\hline & & & Kepala & Toraks & Abdomen \\
\hline Cianjur & $1200-1207$ & $20,7 \pm 0,72$ & Dark brown & $\begin{array}{l}\text { Olive brown- } \\
\text { Dark brown }\end{array}$ & Dark brown \\
\hline Bogor & $394-290$ & $25,5 \pm 0,73$ & Olive brown & Olive brown & Dark brown \\
\hline Cirebon & $21-27$ & $26,7 \pm 0,08$ & Olive brown & Olive brown & $\begin{array}{l}\text { Dark yellowish } \\
\text { brown }\end{array}$ \\
\hline $\mathrm{X}^{2}$ hitung & & & 60,694 & 61,064 & 93,329 \\
\hline$X^{2} 0,05$ & & & 12,592 & 12,592 & 12,592 \\
\hline$X^{2} 0,01$ & & & 16,812 & 16,812 & 16,812 \\
\hline
\end{tabular}


pada spesies serangga lain, suhu yang lebih rendah cenderung meningkatkan ekspresi gen melanisasi pada serangga, sehingga serangga yang hidup pada lingkungan suhu lebih rendah umumnya berwarna lebih gelap. Hal ini didukung oleh hasil penelitian Fischer \& Karl (2010). Parkash et al. (2009) menyatakan bahwa melanisasi berkorelasi negatif dengan suhu dan kelembapan.

Selain akibat pengaruh genetik, perbedaan warna pada tubuh serangga juga merupakan salah satu mekanisme adaptasi serangga tersebut terhadap lingkungan hidupnya. Forsman et al. (2002) menyatakan bahwa warna tubuh serangga berasosiasi dengan upaya serangga tersebut mengurangi resiko hipotermia atau overheating.

\section{KESIMPULAN}

Berdasarkan penjabaran, dapat disimpulkan bahwa ukuran panjang tubuh, lebar toraks dan panjang sayap berkorelasi dengan ketinggian tempat. Ukuran lebar kepala merupakan karakter yang kurang kuat dibandingan tiga karakter ukuran tubuh lainnya. Warna tubuh trips berkorelasi dengan ketinggian.

\section{DAFTAR PUSTAKA}

Anagnou-Veroniki, Souliotis P, Karanastasi, Giannopolitis. 2008. New records of plant pests and weeds in Greece, 190-2007.
Review. Hellenic Plant Protection J. 1:55-78.

Berger D, Walters R, Gotthard K. 2008. What limits insect fecunddity? Body size-and temperature-dependent egg maturation and oviposition in a butterfly. Funct Ecol 22:523-529.

Blackman RL, Spence JM. 1994. The effects of temperature on aphid morphology, using a multivariate approach. Jur J Entomol 91:722.

[CU] California University. 2009. Thrips parvispinus. http://keys. lucidcentral.org/keys/v3/trips_ of_california/data/key/thysanopt era/Media/Html/browse_species/ Trips_parvispinus.htm. [accessed in 22 September 2010].

Dixon AFG. 1985. Aphid Ecology. New York: Blackie.

Fischer K, Karl I. 2010. Exploring plastic and genetic responses to temperature variation using copper butterflies. Clim Res 43: 1730.

Forsman A, Ringblom K, Civantos E, Ahnesjo J. 2002. Coevolution of color pattern and thermoregulatory behavior in polymorphic pygmy grasshoppers Tetrix undulata. Evol 56(2):349-360.

Honek A, Furlan L. 1995. Color polymorphism in Agriotes ustulatus (Coleoptera: Elateridae) absence of geographic and temporal variation. Jur J Entomol 92:437442.

Kalshoven LGE. 1981. The Pest of Crop in Indonesia. Lan PA van der, penerjemah. Jakarta: Ichtiar 
Baru-van Hoeve. Terjemahan dari: De Plagen van de Cultuurgewassengin Indonesia.

Klose MJ et al. 1996. Transmission of three strains of Tobacco streak ilarvirus by different trips species using virus-infected pollen. J Phytopathology 144:281-284

Lewis T. 1973. Thrips: Their Biology, Economic, and Economic Importance. London: Academic Press.

Moritz G, Mound LA, Morris DC, Goldarazena A. 2001. Pest Thrips of the World [CD-ROM]. Australia CSIRO Publishing. CD-ROM dengan penuntun di dalamnya.

Mound LA, Azidah AA. 2009. Species of the genus Thrips (Thysanoptera) from Peninsular Malaysia with a checklist of recorded Thripidae. Zootaxa 2023:55-68.

Mound LA, Collins DW. 2000. A Southeast Asian pest species newly recorded from Europe: Thrips parvispinus (Thysanoptera: Thripidae), its confused identity and potential quarantine significance. Jur J Entomol 97:197-200.

Mound LA, Kibby G. 1998. Thysanoptera an Identification Guide. $2^{\text {nd }}$ ed. London: CAB International.

Murai T, Toda S. 2002. Variation of Thrips tabaci in color and size. Thrips and Topoviruses: Proceedings of the $7^{\text {th }}$ International Symphosium on Thysanoptera. $\mathrm{p}$ 377-378.
Nahrung HF, Allen GR. 2005. Maintainance of colorpolymorphism in the leaf beetle Chrysophtharta agricola (Chapuis) (Coleoptera: Paropsini). J Nat History 39:79-90.

Oliveira CM, Lopes JRS, Dias CTDS, Nault LR. 2004. Influence of latitude and elevation on polymorphism among populations of the corn leafhopper, Dalbulus maidis (DeLong and Wolcott) (Hemiptera: Cicadellidae), in Brazil. Env Entomol 33(5):11921199.

Parkash R, Rajpurohit S, Ramnivas S. 2009. Impact of darker, intermediate and lighter phenotypes of body melanization on desication resistance in Drosophila melanogaster. J Insect Sci 9(49):110

Prabaningrum L, Moekasan TK. 1996. Hama-hama tanaman cabai merah dan pengendaliannya. Di dalam: Duriat AS, Hadisoeganda AWW, Soetiasso TA, Prabaningrum L (ed.), Teknologi Produksi Cabai Merah. Bandung: Balai Penelitian Tanaman Sayur.

Sastrowiswojo S. 1991. Thrips on vegetables in Indonesia. In: Talekar NS (ed.), Thrips in Southeast Asia. Proc. regional Consultation Workshop; Bangkok, 13 March 1991. AVRDC. Taiwan. ROC. p 12-17.

Schoonhoven LM, Van Loon JJA, Dicke M. 2005. Insect-Plant Biology. $2^{\text {nd }}$ ed. New York: Oxford University Press.

Vos JGM. 1994. Pengelolaan Tanaman Terpadu pada Cabai (Capsi- 
cum spp.) di Dataran Rendah

Tropis. Belanda: Universitas Wageningen. insect: state of the art, recent surprises, and future direction. Integr Comp Biol 43:607-616.

Zera AJ. 2004. The endoctrine regulation of wing polymorphism in 